\title{
PENGARUH KUALITAS JASA TERHADAP LOYALITAS PELANGGAN INDOSAT IM3 PRABAYAR DI DESA SANGKANHURIP KABUPATEN BANDUNG
}

\author{
Asep Suwarna \\ Widia Sumitro \\ STIE Muhammadiyah Bandung \\ J1. Karapitan No.143 Bandung
}

\begin{abstract}
Abstrak
Penelitian ini dilatarbelakangi oleh kondisi persaingan bisnis industri telekomunikasi dari waktu ke waktu yang semakin ketat, sehingga perusahaan harus membuat strategi pemasaran baru untuk mempertahankan dan meraih pangsa pasar yang lebih tinggi. Adapun yang menjadi masalah penelitian ini adalah "Apakah kualitas produk berpengaruh terhadap loyalitas pelanggan Indosat IM3 Prabayar di Desa Sangkanhurip". Penelitian ini mencoba mengetahui faktor-faktor yang mempengaruhi konsumen melakukan loyalitas pelanggan terhadap produk IM3 khususnya pada Pelanggan yang menggunakan produk IM3 di Desa Sangkanhurip.

Tujuan penelitian ini untuk menganalisis pengaruh setiap variabel, kualitas produk (X) terhadap loyalitas pelanggan (Y). Dalam penelitian ini data dikumpulkan melalui metode kuesioner terhadap 31 orang responden pengguna produk IM3 di Desa Sangkanhurip dengan mengunakan metode Kuota Sampling dan purposive sampling.

Kemudian dilakukan analisis terhadap data-data yang diperoleh berupa analisis kuantitatif. Analisis kuantitatif meliputi uji validitas dan reliabilitas, Uji Normalitas, uji hipotesis lewat uji t serta uji analisis koefisien determinasi (R2). Teknik analisis data yang digunakan adalah analisis regresi linear Sederhana yang berfungsi untuk membuktikan hipotesis penelitian. Data-data yang telah memenuhi uji validitas, uji reliabilitas, dan Uji Normalitas diolah sehingga menghasilkan persamaan regresi sebagai berikut : $\mathrm{Y}=4,587+0,655$ Hasil analisis mendapatkan bahwa kualitas produk, memiliki pengaruh positif dan signifikan terhadap loyalitas pelanggan.

Pengujian hipotesis menggunakan uji t menunjukkan bahwa variabel independen yang diteliti terbukti secara signifikan mempengaruhi variabel dependen loyalitas pelanggan. Angka Adjusted $R$ square sebesar 0,67 menunjukkan bahwa 67\% variasi loyalitas pelanggan bisa dijelaskan oleh variabel independen yang digunakan dalam persamaan regresi. Sedangkan sisanya sebesar $33 \%$ dijelaskan oleh variabel lain diluar variabel yang digunakan dalam penelitian ini.
\end{abstract}

Kata kunci : kualitas produk, Loyalitas Pelanggan.

\section{PENDAHULUAN}

Teknologi komunikasi saat ini tidak hanya menjadi kebutuhan masyarakat umum tetapi juga menjadi ladang bisnis yang prospektif. Bisnis operator selular dari tahun ke tahun terus meningkat seiring perkembangan jaman.
Selain itu didukung pula dengan hadirnya telepon selular murah yang mampu dijangkau berbagai lapisan masyarakat hingga bisnis operator selular pun makin menjamur di Indonesia. Pergerakan pasar telepon seluler kini sudah merambah kalangan masyarakat menengah bawah. 
Mungkin inilah hasil manis dari diberlakukannya Undang-undang RI no.36/1999 tentang telekomunikasi yang memberikan pondasi bagi kompetisi pasar telekomunikasi di Indonesia. Laporan kinerja 3 Operator selular terbesar di indonesia.

Tabel 1.Tabel jumlah pelanggan 3 Operator terbesar di Indonesia

\begin{tabular}{|l|c|c|}
\hline $\begin{array}{c}\text { Operator } \\
\text { seluler }\end{array}$ & $\begin{array}{c}\text { Pengguna } \\
\text { pada Q1 } \\
\text { 2014(juta) }\end{array}$ & $\begin{array}{c}\text { Pengguna } \\
\text { pada Q3 } \\
2014(\text { juta })\end{array}$ \\
\hline TELKOMSEL & 132,7 & 139,2 \\
\hline XL AXIATA & 62,9 & 58,3 \\
\hline INDOSAT & 59,7 & 54,3 \\
\hline
\end{tabular}

Dapat kita lihat dari mulai telkomsel sebagai operator seluler terbesar perusahaan ini dilaporkan mengalami peningkatan jumlah pengguna yang cukup signifikan. Dari sisi pelanggan data, penggunaan telkomsel mencapai angka 63,5 jt dengan peningkatan trafik data mencapai 146,1 \%. Selain itu telkomsel juga memiliki 34,5 jt pengguna smartphone.

Sedangkan XL Axiata sebagai operator seluler terbesar kedua dilaporkan mengalami penurunan. Dan berdampak kepada jumlah pelanggan data XL Axiata dilaporkan mencapai angka 3,2 juta pada Q1 dan 31,2 jt pada Q3. walau mengalami penurunan jumlah pelanggan data, perusahaan mengklaim mengalami peningkatan trafik data sebanyak $136 \%$ di banding pada periode yang sama pada tahun lalu. Selain itu XL Axiata mengklaim memiliki 14,6 jt pengguna smartphone.

Selanjutnya indosat sebagai operator terbesar ketiga juga mengalami penurunan yang signifikan indosat memiliki 59,7 juta pelanggan pada Q1 , sedangkan menurut indo telkom jumlah pelanggan perusahaan ini berkurang menjadi 54,3 jt pada Q3. namun indosat mengklaim telah mengalami peningkatan trafik data yang signifikan dengan total 55.467 terabyte di banding tahun lalu.

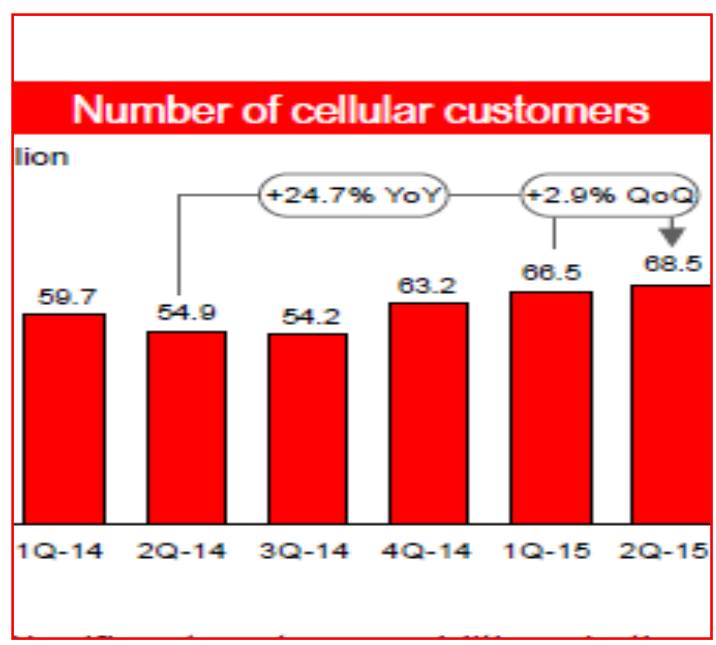

\section{Gambar 1.Grafik Penurunan}

Pelanggan Indosat Perkuartal

Sumber : www.Indosatooredoo.com

indosat sebagai operator terbesar ketiga mengalami penurunan yang signifikan indosat memiliki 59,7 juta pelanggan pada Q1 , Target yang ingin dicapai Indosat adalah tercipta citra anak muda tidak lengkap jika tidak menggunakan IM3. Selain itu, lewat berbagai aktivitas yang dilakukan Indosat berupaya pula menciptakan ikatan emosional di antara pelanggannya. Mulai dari membuat blog sampai download dari internet. Dari voicecall sampe video call, juga memungkinkan penggunaan Blackberry dan Smartphone. Saat ini, IM3 sedang melakukan program murah, dengan mengirim 10 SMS maka akan mendapatkan 100 SMS. Biaya menelepon pun termasuk murah, dengan harga hanya Rp 0,1 perdetik seharian. Pelanggan juga dimanjakan dengan bermacam-macam fitur dari iRing, sampai ke fitur BlackBerry (http://www.anneahira.com).

Setiap tahunnya Indosat selalu mengalami gangguan baik dari segi jaringan dan hal-hal lain beberapa kasus yang sering terjadi hilangnya sinyal secara tiba-tiba. Indikasi secara tekhnis sering 
terjadi anomali traffic di sisi IP MPLS yang menyebabkan kelebihan beban di perangkat indosat. (http://okezone.com). peribahasa "ada uang ada barang" nampaknya juga berlaku pada IM3. Tariff yang murah dan fitur canggih yang lengkap tak menjadikan IM3 selalu mampu memuaskan hati para pelanggannya. Banyaknya keluhan pelanggan membuat IM3 terkadang terperosok pada motto yang dibuat oleh Indosat sendiri yaitu "Sinyal Kuat Indosat" karena pada kenyataannya memang sinyal Indosat dan terutama IM3 bisa dibilang sangat buruk dibanding para pesaingnya. Sinyal IM3 terkadang hilang pada saat musim hujan.

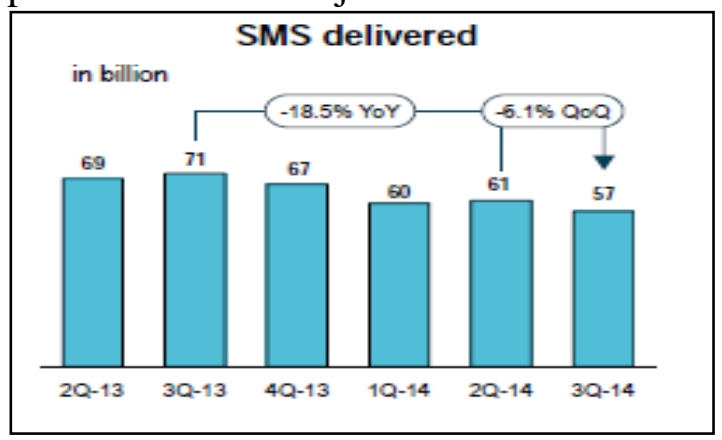

Gambar 2. Data Penurunan SMS Terkirim Perkuartal

Sumber : www.Indosatooredoo.com

$\begin{array}{lll}\text { Dari data diatas } & \text { digambarkan } \\ \text { bahwa } & \text { presentase } & \text { keberhasilan }\end{array}$ pengiriman SMS mengalami penurunan setiap quartalnya yang menandakan bahwa sinyal IM3 belum bisa disandingkan dengan kualitas sinyal pesaing utamanya yaitu produk Telkomsel.

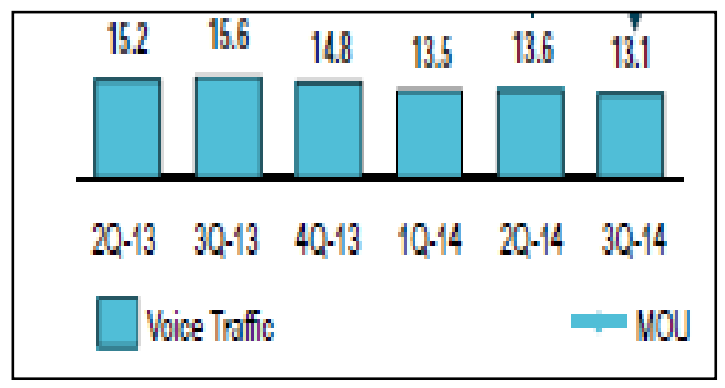

\section{Gambar 3. Data Penurunan}

Penerimaan Telpon perkuartal

Sumber : www.Indosatooredoo.com

Grafik presentase diatas menunjukkan Presentasi penerimaan telepon mengalami penurunan hingga hampir 20\%. Hal ini menunjukkan bahwa kualitas sinyal IM3 belum bisa disandingkan dengan kualitas sinyal pesaingnya. Dari data diatas dapat dilihat bahwa tingkat kegagalan telepon dan SMS dari IM3 tergolong tinggi, Hal ini kontan dapat mengurangi tingkat kepercayaan pelanggan pada produk IM3. Memahami perilaku tertentu dari pelanggan akan memberikan pemahaman yang lebih jelas tentang kepuasan dan loyalitas mereka. Pelanggan yang tidak puas tampaknya tidak selalu menunjukkan perilaku yang sama. Sebagian dari mereka mungkin akan menyuarakan ketidakpuasan dengan mengajukan keluhan (complain), tetapi tidak sedikit pula dari mereka yang memilih untuk diam. Peneliti melakukan penelitian di Desa Sangkanhurip dikarenakan seringnya saya temukan keluhan dari para pelanggan Indosat di beberapa konter di Desa Sangkanhurip. Peneliti melakukan pendekatan kepada konsumen dengan cara mewawancarai dan membagikan kuesioner kepada pelanggan Indosat yang hendak membeli pulsa di beberapa konter. Dibawah ini merupakan tabel keluhan pelanggan yang diwawancarai oleh peneliti sebelum pengujian kuisioner di desa Sangkanhurip.

Tabel 2. Tabel Keluhan Pelanggan

\begin{tabular}{|c|c|l|}
\hline no & Pelanggan & \multicolumn{1}{|c|}{ Keluhan } \\
\hline \multirow{2}{*}{1} & $\begin{array}{c}\text { Wiraswasta } \\
\text { (Perempuan, } \\
45 \text { th) }\end{array}$ & $\begin{array}{l}\text { Saya pengguna IM3 } \\
\text { selama 1th, terlalu } \\
\text { sering sinyal hilang } \\
\text { tiba-tiba ketika saya } \\
\text { menelpon. }\end{array}$ \\
\hline 2 & $\begin{array}{c}\text { Pelajar } \\
\text { (Perempuan, } \\
\text { 15th) }\end{array}$ & $\begin{array}{l}\text { Kadang sms yang } \\
\text { saya kirim bisa } \\
\text { sampai 1hari, terlalu }\end{array}$ \\
\hline
\end{tabular}




\begin{tabular}{|c|c|l|}
\hline & sering terjadi \\
gangguan
\end{tabular}

Sumber: Hasil Wawancara 2015

Pelanggan yang puas berarti tidak memiliki keluhan terhadap performa penyedia jasa. Hampir dapat dipastikan bahwa kelompok pelanggan ini akan kembali lagi kepada penyedia jasa yang sama. Kondisi seperti ini mencerminkan terbentuknya loyalitas pelanggan (Harsoyo, 2009). Data diambil dari gerai Indosat dan juga Web resmi Indosat www.indosatooredoo.com.

\section{KERANGKA HIPOTESIS \\ Loyalitas Pelanggan}

TEORITIS

Menurut Tjiptono (2000 : 110)

Loyalitas Pelanggan adalah komitmen pelanggan terhadap suatu merek, toko atau pemasok berdasarkan sifat yang sangat positif dalam pembelian jangka panjang. Dari pengertian ini dapat diartikan bahwa kesetiaan terhadap merek diperoleh karena adanya kombinasi dari kepuasan dan keluhan. Sedangkan kepuasan pelanggan tersebut hadir dari seberapa besar kinerja perusahaan untuk menimbulkan kepuasan tersebut dengan meminimalkan keluhan sehingga diperoleh pembelian jangka panjang yang dilakukan oleh konsumen.

Menurut ( Oliver : 1996:392; dikutip oleh, DR. Ratih Hurriyati, M.SI : 125)

" Customer loyality is deefly held commitment to rebuy or repatronize a preferred product or service cost sistenly in the future, despite situational influences and marketing efforts laving the potential to cause switching behavior."

Dari definisi diatas dapat dilihat bahwa loyalitas adalah komitmen pelanggan bertahan secara mendalam untuk berlangganan kembali atau melakukan pembelian silang produk bisa terpilih secara konsisten di masa yang akan datang, meskipun pengaruh situasi dan usaha- usaha pemasaran mempunyai potensi untuk menyebabkan perubahan perilaku.

Sedangkan menurut ( Griffin : 2002: 4; dikutip oleh, DR. Ratih Hurriyati, M.SI : 125)

"Loyalty is defined as non random purchase expressed over time by some decision making unit."

Berdasarkan definisi tersebut dapat di jelaskan bahwa loyalitas lebih mengacu pada wujud perilaku dari unit -unit pengambilan keputusan untuk melakukan pembelian secara terus menerus terhadap barang atau jasa suatu perusahaan yang dipilih.

Loyalitas menurut ( Hermawan : 2003: 126; dikutip oleh, DR. Ratih Hurriyati, M.SI : 126)

Merupakan manifestasi dari kebutuhan fundamental manusia untuk memiliki, mensuport, mendapatkan rasa aman dan membangun keterikatan serta menciptakan emotional attachment. Sedangkan loyalitas dalam The Oxford english dictionary adalah " a strong feeling of support and allegience, a person showing firm and constantt support" definisi tersebut terdapat kata Strong Feeling artinya kedalaman perasaan manusia terhadap suatu hal, apakah keluarga, teman, organisasi, atau merek perasaan inilah yang menjadi unsur utama dan menentukan loyalitas pelanggan.

Dan menurut ( Fandy Tjiptono, Ph.D \& Gregorius Chandra, 2012:80). mengatakan bahwa : 
"Loyalitas pelanggan sebagai komitmen pelanggan terhadap suatu merek toko pemasok, berdasarkan sikap yang sangat positif tercermin dalam pembelian ulang yang konsisten."

Loyalitas pelanggan merupakan dorongan perilaku untuk melakukan pembelian secara berulang-ulang dan untuk membangun kesetiaan pelanggan terhadap suatu produk atau jasa yang dihasilkan oleh perusahaan tersebut membutuhkan waktu yang lama melalui suatu proses pembelian yang berulangulang. Pelanggan berbeda dengan konsumen seseorang dapat dikatakan pelanggan apabila seseorang tersebut mulai membiasakan diri untuk membeli produk atau jasa yang ditawarkan oleh perusahaan. Kebiasaan tersebut dapat di bangun melalui pembelian berulang-ulang dalam jangka waktu tertentu, apabila dalam jangka waktu tertentu tidak melakukan pembelian ulang,maka seseorang tersebut tidak dapat dikatakan sebagai pelanggan tetapi sebagai konsumen. ( Fandy Tjiptono, Ph.D \& Gregorius Chandra, 2012:81).

Riset loyalitas pelanggan dalam beberapa dekade terakhir menghasilkan lima wawasan manajerial penting. ( Fandy Tjiptono, Ph.D \& Gregorius Chandra, 2012:81).

1. Riset-riset berdasarkan perspektif behavioral menemukan bahwa hanya sedikit konsumen yang tergolong loyal monogami (100\% loyal) atau "promiscuous" (tidak loyal terhadap merk apapun).sebaliknya, yang sering dijumpai justru fenomena polygamous loyality, yaitu pelanggan loyal terhadap portofolio merk tertentu dalam suatu kategori produk. Walaupun anda sangat menyukai produk tersebut sangat sulit membayangkan jika anda mengkonsumsinya setiap saat. Fenomena polygamous loyality dikarenakan sejumlah faktor, diantaranya : a. Konsumen menggunakan merk berbeda untuk situasi berbeda (contohnya sepatu untuk main basket, sepatu untuk main sepak bola)

b. Merek-merek bersifat komplementer bukan substitusi (contohnya konsumen membeli kompas untuk berita umum harian )

c. Kadangkala konsumen merasa perlu menggabungkan berbagai merek dalam rangka membentuk produk lengkap (contohnya pakaian, kosmetik, travel)

d. Beberapa merek tidak menawarkan layanan lengkap sebagaimana diharapkan (contohnya pengecer, saluran tv, pemancar radio)

e. Variasi merupakan manfaat yang dicari pelanggan (contohnya konsumen mencoba masakan yang berbeda-beda dari beragam negara)

f. Hasrat akan sesuatu yang baru (suka mencoba hal-hal yang baru)

g. Anggota keluarga menginginkan merek berbeda (contohnya, Shampo, sabun mandi )

h. Dalam situasi "out of stock" di pasar swalayan banyak orang bersedia membeli merek lain dalam kategori yang sama dari pada pindah ke toko lain.

i. Diferensiasi yang kurang signifikan dan kemiripan fungsional antar merek dalam sebuah kategori produk membuat banyak konsumen gampang beralih dari satu merek ke merek lain, konsekuensinya, jarang ada konsumen yang loyal 100\% hanya pada satu merek saja.

( Fandy Tjiptono, Ph.D \& Gregorius Chandra, 2012:81).

2. Loyalitas pelanggan bersifat dinamis dan bisa berubah di karenakan berbagai faktor, seperti kondisi kesehatan, perubahan tahapan dalam siklus hidup, aktivitas promosi perusahaan, perubahan 
pendapatan, normal subyektif, dan sebagainya.

3. Merek-merek kecil cenderung mengalami kerugian gand di mana hanya sedikit konsumen yang membelinya (pangsa pasar kecil) dan dari mereka yang membelinya tersebut hanya membeli dalam jumlah dan frekuensi kecil, serta cenderung kurang loyal.

4. Ada hubungan negatif antara kesuksesan Private-Label Brands (store brands) dan siklus bisnis. Pangsa PrivateLabel Brands di sebuah negara meningkat manakala kondisi perekonomian memburuk dan sebaliknya menurun saat perekonomian membaik, fenomena ini diamati oleh beberapa negara.

5.Secara garis besar karakteristik dan ukuran loyalitas pelanggan bisa dibedakan berdasarkan tiga tipe pasar. ( Fandy Tjiptono, Ph.D \& Gregorius Chandra, 2012:82).

a. Consumable Goods Markets, Riset loyalitas merek pada tipe pasar ini cenderung difokuskan pada ukuran behavioral loyalitas, seperti proporsi pembelian dan periode waktu menggunakan merek tertentu. Consumable goods bercirikan divide loyalty, yang biasa dikenal pula dengan multi brand purchasing, alasan pembelian berbagai macam merek bisa bermacam-macam, diantaranya demi mencari variasi, memanfaatkan kesempatan diskon atau merek favorit sedang tidak tersedia, pembeli tunggal membeli untuk kebutuhan rumah tangga, tingkat keterlibatan rendah dalam pembelian ulang, jumlah transaksi pembelian biasanya kecil.

b. Durable Goods Markets, adalah produk manufaktur yang berumur lama hal ini berarti pelanggan membeli barang semacam ini, maka ia akan secara temporer "out of the market" untuk produk bersangkutan , setidaknya sampai ia membutuhkan produk pengganti atau melakukan pembelian ulang. Karakteristik loyalitas pada tipe ini meliputi : pembeli biasanya tidak berganti merek sesering pembelian consumable goods dan dalam setiap periode waktu tertentu, pembeli tergolong sole loyal atau mungkin pula dua loyal artinya merek tertentu menikmati posisi share of category requirements $100 \%$ misalnya dalam satu keluarga hanya menggunakan printer canon maka share of category requirements printer canon tersebut adalah $100 \%$.

c. Service Markets bercirikan (1) konsumen jasa cenderung lebih loyal pada merek tertentu dan menghindari peralihan merek untuk meminimumkan persepsi terhadap resiko, (2) pelanggan biasanya adalah sale loyal dengan $100 \%$ share of category requirements untuk merek tertentu contohnya jasa pendidikan, salon kecantikan, konsultasi hukum, (3) konsumen jasa berkemungkinan tetap setia dengan penyedia jasa tertentu apabila telah terjalin relasi yang akrab diantara mereka, (4) sulitnya mengevaluasi kualitas jasa menyebabkan loyalitas merek lebih sering dijumpai dalam sektor jasa terutama apabila konsumen telah familiar dengan penyedia jasa tertentu, (5) loyalitas dalam beberapa pasar jasa merefleksikan intersia. ( Fandy Tjiptono, Ph.D \& Gregorius Chandra, 2012:84).

\section{Tingkatan Loyalitas}

Jika kategori jasa dapat diperingkat untuk mencerminkan tingkat nilai yang terdapat dalam layanan demikian pula dengan kelompok pelanggan.Dalam hal tersebut, tingkatan jasa dapat dikembangkan berdasarkan tingkat kontribusi laba dari berbagai 
kelompok pelanggan dan kebutuhan mereka (mencakup kepekaan terhadap variabel-variabel seperti harga, kenyamanan, dan kecepatan) dan profil individu seperti data kependudukan Zeithaml, Rust, dan lemon dalam buku (lovelock,2011:89) mengilustrasikan prinsip melalui piramida empat tingkatan:

- Platinum, Pelanggan ini hanya menduduki persentase yang amat kecil dalam Basis pelanggan perusahaan, tetapi mereka adalah pengguna besar dan memberikan kontribusi yang besar terhadap harga tetapi mengharapkan tingkatan layanan yang paling tinggi dan cenderung berinvestasi dan mencoba layanan baru.

- Emas, pelanggan ini persentase nya lebih besar ketimbang platinum tetapi pelanggan individu memberikan keuntungan yang lebih kecil ketimbang pelanggan platina, mereka cenderung sedikit lebih peka terhadap harga dan kurang berkomitmen terhadap peusahaan.

- Besi, pelanggan ini menjadi bagian besar dalam basis pelanggan, jumlah mereka yang besar memberikan skala ekonomis bagi perusahaan, dengan demikian, mereka sering kali penting sehingga perusahaan dapat membangun dan memelihara tingkat kapasitas dan infrastruktur tertentu. yang sering kali diperlukan dalam melayani pelanggan emas dan platinum. Akan tetapi ,pelanggan besi sering kali hanya sedikit menguntungkan. Tingkatan bisnis yang dilakukan dari mereka kurang cukup untuk memberikan perlakuan khusus.

- Timbal, pelanggan pada tingkatan ini cenderung menghasilkan penerimaan yang rendah bagi perusahaan tetapi sering kali menginginkan layanan yang sama seperti pelanggan besi, sehingga menjadikan pelanggan jenis sebagai segmen yang merugikan dari sudut pandang perusahaan.
Sedangkan empat tingkatan loyalitas menurut Griffin : 2007: 31, dikutip oleh (DR. Ratih Hurriyati, M.SI, 2010 : 131) adalah sebagai berikut :

1. Tanpa Loyalitas

Untuk berbagai alasan, beberapa pelanggan tidak mengembangkan loyalitas terhadap produk atau jasa tersebut dikombinasikan dengan tingkat pembelian berulang yang rendah menunjukan tidak adanya loyalitas. Secara umum perusahaan harus menghindar membidik para pembeli jenis ini karena mereka tidak akan pernah menjadi pelanggan yang loyal

2. Loyalitas yang Lemah

Keterikatan yang rendah digabung dengan pembelian yang tinggi menghasilkan loyalitas yang lemah (inertia loyality). Pelanggan ini memebeli karena kebiasaan ini adalah jenis pembelian "Karena kami selalau menggunakannya" atau "Karena sudah terbiasa" dengan kata lain, faktor nonsikap dan faktor situasi merupakan alasan utama untuk membeli.

3. Loyalitas Tersembunyi

Tingkat preferensi yang relatif tinggi digabung dengan tingkat pembelian berulang yang rendah menunjukan loyalitas tersembunyi (latent loyalty). Bila pelanggan memiliki loyalitas yang tersembunyi, pengaruh situasi dan bukan pengaruh sikap yang menentukan pembelian berulang. Dengan faktor situasi yang berkontribusi pada loyalitas tersembunyi, perusahaan dapat menggunakan strategi untuk mengatasinya.

4. Loyalitas Premium

Loyalitas premium, jenis loyalitas yang paling dapat ditingkatkan, terjadi bila ada tingkat ketertarikan yang tinggi dan tingkat pembelian berulang yang juga tinggi. Ini merupakan jenis loyalitas yang lebih disukai untuk semua 
pelanggan disetiap perusahaan. Pada tingkat preferensi paling tinggi tersebut, orang bangga karena menenukan dan menggunakan produk tertentu dan senang membagi pengetahuan mereka dengan rekan atau keluarga.

\section{Karakteristik Loyalitas}

Griffin : 2007: 31 dikutip oleh

(DR. Ratih Hurriyati, M.SI : 130)

Loyalitas dapat didefinisikan berdasarkan perilaku membeli. Adapun Karakteristik pelanggan yang loyal adalah orang yang :

1. Melakukan pembelian berulang yang teratur

Pelanggan yang telah melakukan pembelian suatu jasa atau produk sebanyak lebih dari dua kali atau lebih.

2. Membeli antar lini produk dan jasa

Pelanggan tersebut membeli semua barang atau jasa yang ditawarkan dan mereka butuhkan. Para pelanggan tersebut membeli secara teratur, hubungan dengan jenis pelanggan ini sudah kuat dan berlangsung lama serta membuat mereka tidak terpengaruh oleh produk pesaing.

3. Mereferensikan kepada orang lain

Membeli barang atau jasa ditawarkan dan yang mereka butuhkan, serta melakukan pembelian secara teratur.selain itu mereka mendorong orang lain agar membeli barang atau jasa perusahaan tersebut. Secara tidak langsung, mereka telah melakukan pemasaran untuk pemasaran untuk perusahaan dan membawa konsumen kepada perusahaan.

4. Menunjukan kekebalan terhadap tarikan dari pesaing

Seorang konsumen dikatakan loyal jika ia mempunyai suatu komitmen yang kuat untuk menggunakan lagi jasa yang diberikan secara rutin. Banyak perusahaan meluncurkan programprogram tertentu yang tujuannya meningkatkan loyalitas konsumen misalnya:

a. Pemberian Reward.

b. Memberikan pelayanan dengan menyajikan keunggulan di mata konsumen.

\section{Membangun Loyalitas Pelanggan}

Roda Loyalitas (Wheel of Loyalty) sebagai kerangka kerja terstruktur mengenai membangun loyalitas pelanggan menurut (Loveloock, Jochen Wirtz, Jacky Mussry, 2011:84) :

1. Membangun fondasi loyalitas :

- Segmentasikan pasar agar sesuai dengan kebutuhan pelanggan dan kemampuan perusahaan.

- Selektif : Mencari pelanggan yang cocok dengan inti proposisi nilai

- Kelola basis pelanggan melalui tingkatan jasa yang efektif

- Menghantarkan jasa berkualitas

2. Menciptakan ikatan loyalitas :

- Membangun ikatan yang lebih tinggi : Sosial, Kustomisasi, Struktural

- Memberikan penghargaan terhadap loyalitas : finansial, nonfinansial layanan dengan tingkatan yang tinggi, pengakuan dan apresiasi

- Memperdalam hubungan via cross selling, bundling

3. Mengurangi faktor perpindahan pelanggan :

- Melakukan diagnostic churn dan mengawasi pelanggan yang mulai kecewa

- Mengatasi faktor-faktor pendorong churn utama : langkah retensi, produktif, langkah retensi, reaktif.

- Melakukan penanganan keluhan dan proses pemulihan jasa yang efektif

- Meningkatkan biaya pengalihan. (Loveloock, Jochen Wirtz, Jacky Mussry, 2011:84) 


\section{Kualitas Jasa}

Kotler dan Keller (2012: 153) menyebutkan kualitas adalah kecocokan untuk digunakan, pemenuhan tuntutan. Sedangkan istilah kualitas sendiri mengandung berbagai macam penafsiran, karena kualitas memiliki sejumlah level : Universal (sama di manapun, Kultural (tergantung sistem nilai budaya), Sosial (dibentuk oleh kelas sosial ekonomi, kelompok etnis, keluarga, teman sepergaulan) dan Personal (tergantung preferensi atau selera setiap individu). Secara sederhana, kualitas bisa diartikan sebagai produk yang bebas cacat. Dengan kata lain. Produk sesuai dengan standar (target, sasaran, atau persyratan yang bisa didefinisikan, diobservasi dan diukur). Namun, definisi berbasis manufaktur ini kurang relevan untuk sektor jasa. Oleh sebab itu, pemaham mengenai kualitas kemudian diperluas menjadi "Fitness Fo Use" dan "Conformance To Requirements" kualitas mencerminkan semua dimensi penawaran produk yang menghasilkan manfaat (benefits) bagi pelanggan istilah nilai (value) seringkali digunakan untuk mengacu pada kualitas relatif suatu produk dikaitkan dengan harga produk bersangkutan.( Fandy Tjiptono, Ph.D \& Gregorius Chandra, 2012:74).

Sehingga yang dimaksud dengan kualitas jasa adalah bagaimana tanggapan konsumen terhadap jasa yang dikonsumsi atau yang dirasakannya di dalam teori mengenai Manajemen Jasa, penilaian ini disebut sebagai Consumer Perceived Service Quality yang mencakup beberapa dimensi kinerja jasa sering kali tidak dapat dievaluasi, sehingga konsumen menggunakan isyarat intrinsik dan isyarat ekstrinsik jasa sebagai acuan. Berkaitan dengan sulitnya bagi konsumen untuk menilai kualitas jasa, dikutip oleh ( Fandy Tjiptono, Ph.D \& Gregorius Chandra, 2012:76).
Mencoba mengembangkan suatu kerangka pemikiran untuk menjelaskan masalah ini, dia membedakan 2 kategori kualitas yang dapat ditawarkan, Isyarat Intrinsik berkaitan dengan output dan penyampaian kualitas yang dapat di evaluasi konsumen sebelum membeli, misalnya warna, aroma, harga dan rasa sedangkan yang dimaksud dengan isyarat Ekstrinsik adalah unsur - unsur yang merupakan pelengkap bagi suatu jasa yang merupakan Experience Quaility dan Credence Quality.

Experience Quaility adalah kualitas yang harga bisa di evaluasi konsumen setelah membeli atau mengkonsumsi jasa pelayanan contohnya Kerapian rambut setelah masuk salon atau kecepatan jasa pengiriman barang.

Credence Quality adalah kualitas yang sukar dievaluasi pelanggan, meskipun telah mengkonsumsi suatu jasa misalya kualitas operasi jantung.

Lebih lanjut, kualitas jasa berkontribusi signifikan bagi pengembangan diferensiasi, positioning, dan strategi bersaing setiap organisasi pemasaran,baik perusahaan manufaktur maupun penyedia jasa. Walaupun begitu, minat dan perhatian pada pengukuran kualitas layanan sebenarnya baru berkembang sejak dalam dekade 1980an. Kualitas jasa mencerminkan perbandingan antara tingkat layanan yang disampaikan perusahaan dibandingkan ekspektasi pelanggan. Kualitas layanan di wujudkan melalui pemenuhan kebutuhan dan keinginan pelanggan serta ketepatan penyampaiannya dalam mengimbangi atau melampaui harapan pelanggan.

Harapan pelanggan bisa berupa tiga standar :

1. Will Expectation, yaitu tingkat kinerja yang diantisipasi atau diperkirakan konsumen akan diterimanya, berdasarkan semua informasi yang diketahuinya. Tipe ini merupakan tingkatan harapan yang 
paling sering dimaksudkan oleh konsumen sewaktu menilai kualitas layanan.

2. Should Expectation yaitu tingkat kinerja yang dianggap sudah sepantasnya diterima konsumen. Biasanya tuntutan dari apa yang seharusnya diterima jauh lebih besar daripada apa yang diperkirakan bakal diterima.

3. Ideal Expectation yaitu tingkat kinerja optium atau terbaik yang diharapkan dapat diterima konsumen. Singkat kata, faktor utama yang mempengaruhi kualitas layanan ada dua; Expected Service dan Perceived Service. ( Fandy Tjiptono, Ph.D \& Gregorius Chandra, 2012:77).

Jenis kesenjangan yang dapat terjadi pada titik-titik yang berbeda selama mendesain dan menyajikan kinerja pelayanan menurut (Loveloock, Jochen Wirtz, Jacky Mussry, 2011:155)

- Gap 1, The Knowledge Gap ( Kesenjangan Pengetahuan) adalah perbedaan antara apa yang menurut manajemen senior diharapkan oleh pelanggan dengan kebutuhan aktual dan harapan konsumen.

- Gap 2, The Policy Gap (Kesenjangan Kebijakan) adalah perbedaan antara pemahaman manajemen terhadap ekspektasi pelanggan dan standar kualitas yang ditetapkan untuk penyajian pelayanan.

- Gap 3, The Delivery Gap (Kesenjangan Komunikasi) adalah perbedaan antara standar pelayanan yang ditetapkan, dan kenyataan kinerja tim penyajian serta pelayanan operasional dilapangan.

- Gap 4, The Communications Gap (Kesenjangan Komunikasi) adalah perbedaan antara apa yang dikomunikasikan perusahaan dan apa yang diterima oleh para pelanggannya.

- Gap 5, The Perceptions Gap (Kesenjangan Persepsi) adalah perbedaan antara apa yang disampaikan kepada pelanggan dan apa yang pelanggan rasa telah mereka terima.
- Gap 6, The Service Quality Gap (Kesenjangan Kualitas Pelayanan) adalah perbedaan antara apa yang di sampaikan kepada pelanggan harapkan untuk mereka terima dan persepsi mereka terhadap pelayanan yang sebenarnya di sampaikan.

\section{Hipotesis}

Hipotesis Penelitian Menurut Sugiyono (2014:64), merupakan jawaban sementara terhadap rumusan masalah penelitian, di mana rumusan masalah penelitian telah dinyatakan dalam bentuk pertanyaan.

Adapun jawaban sementara dari penelitian ini adalah adanya pengaruh yang signifikan Kualitas produk dengan Loyalitas Konsumen.

$>$ Ho $=$ Tidak terdapat pengaruh kualitas jasa terhadap loyalitas pelanggan

$>\mathrm{Ha}=$ Terdapat pengaruh signifikan kualitas jasa terhadap loyalitas pelanggan

\section{METODE PENELITIAN}

Metode penelitian yang digunakan adalah metode deskriptif. Menurut (M. Nazir,2005:57), metode deskriptif adalah suatu metode dalam meneliti status kelompok manusia, suatu objek, suatu setting kondisi, suatu sistem pemikiran, ataupun suatu kelas peristiwa pada masa sekarang.

Tujuan dari penelitian deskriptif ini adalah untuk membuat deskripsi, gambaran, atau lukisan secara sistematis, faktual, dan akurat mengenai fakta - fakta, sifat - sifat, serta hubungan antar fenomena yang diselidiki. Studi kasus merupakan penelitian yang terperinci mengenai suatu obyek tertentu selama kurun waktu tertentu, termasuk lingkungan dan kondisi masa lalunya dengan cukup mendalam dan menyeluruh.

\section{Populasi dan Sampel}

$\begin{array}{lrr}\text { Populasi adalah } & \text { wilayah } \\ \text { generalisasi yang terdiri atas: }\end{array}$ 
obyek/subyek yang mempunyai kualitas dan karakteristik tertentu yang ditetapkan oleh penelitian untuk dipelajari dan kemudian ditarik kesimpulannya (Sugiyono, 2011:117-118).

Dari pengertian tersebut, maka yang akan menjadi populasi adalah jumlah pelanggan pengguna kartu prabayar indosat IM3 .

Sampel adalah bagian dari jumlah dan karakteristik yang dimiliki oleh populasi. Sampel dilakukan jika populasi besar dan peneliti tidak mungkin mempelajari semua yang ada pada populasi (Sugiyono, 2011:118-127)

Adapun teknik pengambilan sampel yang akan digunakan adalah sampling kuota dan Purposive sampling.

Sampling Kuota dan Purposive Sampling merupakan bagian dari pengambilan sempel secara non probability, pengertian dari non probability sendiri adalah tekhnik pengambilan sampel yang tidak memberi peluang atau kesempatan sama bagi setiap unsur atau anggota populasi untuk dipilih menjadi sampel.(Sugiyono:84 :2014) sedangkan pengertian sampling kuota adalah tekhnik untuk menentukan sampel dari populasi yang mempunyai ciri-ciri tertentu sampai jumlah kuota yang digunakan (sugiyono:85:2014).

Sedangkan Purposive Sampling adalah tekhnik Penentuan sampel dengan pertimbangan (sugiyono:96:2014)., tertentu menggabungkan kedua tekhnik tersebut agar data yang dihasilkan bisa maksimal. Untuk menentukan jumlah sampel di ambil melalui teori Roscoe dalam buku Research Methods For Business (1982:253) yang dikutip kembali oleh (Sugiyono : 90-91:2014).

Memberikan saran-saran tentang ukuran sampel yang layak dalam peneilitian adalah 30 sampai 500. Jumlah penduduk di desa Sangkanhurip berjumlah 24.402 orang dikarenakan keterbatasan waktu yang tidak memungkinkan dan tidak diketahuinya jumlah pelanggan indosat IM3 di Desa Sangkanhurip maka peneliti menggunakan metode sampling kuota dengan ukuran sampel sebanyak 31 orang sampel yang mempunyai ciri- ciri tertentu yaitu :

1. Memiliki kartu perdana indosat IM3 lebih dari 3 bulan.

2. Menggunakan salah satu layanan kartu Indosat IM3 seperti sms dan telepon, dan paket data internet.

3. Bertempat tinggal di Desa Sangkanhurip.

\section{Metode Analisis Data \\ Uji Validitas}

Menurut Sugiyono (2014:152)

bahwa instrument yang valid / sah adalah alat ukur yang digunakan untuk mendapatkan data yang valid dan dapat digunakan untuk mengukur apa yang akan diukur. Dalam pemahaman ini, sebuah kuisioner yang berisi beberapa pernyataan, untuk mengukur satu hal dan dinyatakan valid, apabila setiap butir pernyataan yang menyusun kuisioner tersebut memiliki keterkaitan yang tinggi.

Ukuran keterkaitan antar butir pernyataan ini umumnya ditandai dengan korelasi/ hubungan jawaban antar pernyataan. Pernyataan yang memiliki korelasi rendah, dinyatakan tidak valid. Metode yang digunakan untuk memberikan penilaian terhadap validitas kuisioner adalah korelasi produk momen (Moment Product Correlation).

Korelasi produk moment untuk mencari pengaruh dan membuktikan hipotesis adanya pengaruh variable $\mathrm{X}$ terhadap variabel $\mathrm{Y}$, digunakan rumus sebagai berikut (Ir Syofian Siregar, MM, 2013:339):

Menurut sugiono (2014: 153) bahwa ketentuan validitas instrument yang kuat, apabila nilai korelasi (r) dihitung lebih besar dari $r$ kritis yaitu 0,3. Selain ini sugiyono menambahkan bahwa bila 
korelasi tiap faktor adalah positif dan besarnya $0,3 \mathrm{ke}$ atas maka validitas instrumen dinyatakan Valid.

\section{Uji Reliabilitas}

Selain memiliki tingkat validitas, alat ukur juga memiliki karakteristik reliabilitas. Sugiyono (2004) menyatakan bahwa reliable berarti instrument tersebut bisa digunakan beberapa kali untuk mengukur objek yang sama akan menghasilkan data yang sama pula.

Uji reliabilitas dilakukan dengan menggunakan metode Alpha Cronbach's yang diukur berdasarkan skala Alpha Cronbach's berupa angka 0 sampai 1,0. Sugiyono menyatakan bahwa jika skala dikelompokan kedalam 5 kelas, dengan range yang sama, maka ukuran kemantapan Alpha Cronbach's dapat diinterpretasikan sebagai berikut:

1. Nilai 0,00 s.d. 0,20 berarti kurang reliable

2. Nilai 0,21 s.d. 0,40 berarti agak reliable

3. Nilai 0,41 s.d. 0,60 berarti cukup reliable

4. Nilai 0,61 s.d. 0,80 berarti reliable

5. Nilai 0,81 s.d. 1,00 berarti sangat reliable

Menurut Sugiyono (2004) bahwa reliabilitas suatu konstruk dinyatakan baik apabila memiliki nilai Alpha Cronbach's lebih besar dari 0,60. Maka pengujian reliabilitas instrument dalam sebuah penelitian dilakukan karena keterhandalan instrument berkaitan dengan taraf kepercayaan terhadap instrument penelitian tersebut.

\section{Teknik Pengukuran Skor}

Teknik pengukuran skor atau nilai yang digunakan dalam penelitian ini adalah memakai skala ordinal untuk menentukan jawaban kuesioner responden yang disebarkan kepada responden (Sugiyono:2014,108).

Untuk menentukan kategori jawaban responden terhadap masingmasing alternatif apakah tergolong sangat tinggi, sedang, rendah, sangat rendah, maka ditentukan kelas intervalnya. Berdasarkan alternatif jawaban responden, maka dapat ditentukan interval kelasnya terlebih dahulu yaitu sebagai berikut:

Skor tertinggi - Skor terendah

Banyaknya bilangan

Maka diperoleh interval sebagai berikut:

$$
i=\frac{5-1}{5}=0,8
$$

Teknik pengukuran frekuensi skor ini digunakan untuk mengetahui gambaran variabel penelitian. Frekuensi skor pada setiap alternatif jawaban angket dihitung sehingga diperoleh presentase jawaban setiap alternatif jawaban. Presentase skor jawaban selanjutnya digunakan untuk mengetahui dan menginterpretasikan kecenderungan jawaban responden pada setiap indikator dan dimensi masingmasing variabel. (sugiyono:2014,109)

\section{Transformasi Data}

Pengumpulan data melalui kuesioner dengan penilaian jawaban angket five option scale, menghasilkan data dengan skala ordinal. Oleh karena itu peneliti harus mentransformasikan data dengan skala ordinal ke Skala Interval untuk memenuhi persyaratan analisis regresi (data harus bersifat interval atau rasio), maka data dalam bentuk skala ordinal tersebut harus ditingkatkan menjadi skala interval.

Peningkatan skala ordinal menjadi interval dalam penelitian ini akan digunakan Method of Successive Intervals (MSI). Dalam MSI, peningkatan skala dari ordinal ke interval ini dilakukan untuk setiap item pada masing-masing variabel Al-Rasyid, 1993:131-134 di kutip oleh (lilis:2014).

Tahapan-tahapan Metode of Successive Interval adalah sebagai berikut:

1. Menentukan frekuensi setiap responden. 
2. Menentukan proporsi setiap responden dengan membagi frekuensi dengan jumlah sampel.

3. Menjumlahkan proporsi secara berurutan untuk setiap respon sehingga diperoleh kumulatif.

4. Menentukan nilai $\mathrm{Z}$ untuk masingmasing proporsi kumulatif yang dianggap menyebar mengikuti sebaran normal baku.

5. Menghitung scale value (SV) terkecil menjadi sama dengan satu (1) dan mentransformasikan masing-masing skala menurut perubahan skala terkecil sehingga diperoleh transformes scale value (TSV).

\section{Uji Normalitas}

Penggunaan Statistik Parametris mensyaratkan bahwa data setiap variabel harus berdistribusi normal maka sebelum melakukan pengujian hipotesis, peneliti terlebih dulu melakukan pengujian normalitas data. Uji normalitas digunakan untuk menguji apakah model regresi mempunyai distribusi normal atau tidak. Asumsi normalitas merupakan persyaratan yang sangat penting pada pengujian kebermaknaan (signifikasi) koefisien regresi. Model regresi yang baik adalah model regresi yang memiliki distribusi normal atau mendekati normal, sehingga layak dilakukan pengujian secara statistik.(Sugiyono,2014:199)

Menurut Singgih Santoso (2002:393) dasar pengambilan keputusan bisa dilakukan berdasarkan probabilitas (Asymtotic Significance), yaitu :

- Jika probabilitas > 0,05 maka distribusi dari populasi adalah normal

- Jika probabilitas <0,05 maka populasi tidak berdistribusi secara normal.

Menurut Singgih Santoso (2002:322), pengujian secara visual dapat juga dilakukan dengan metode gambar normal probability plots dalam SPSS. Dasar pengambilan keputusan berdasarkan :
- Jika data menyebar disekitar garis diagonal dan mengikuti arah garis diagonal, maka dapat disimpulkan bahwa model regresi memenuhi asumsi normalitas.

- Jika data menyebar jauh dari garis diagonal dan tidak mengikuti arah garis diagonal, maka dapat disimpulkan bahwa model regresi tidak memenuhi asumsi normalitas.

Selain itu uji normalitas digunakan untuk mengetahui bahwa data yang diambil berasal dari populasi berdistribusi normal. Uji yang digunakan untuk menguji kenormalan adalah menggunakan uji Kolmogorov-Smirnov. Berdasarkan sampel ini akan diuji hipotesis nol bahwa sampel tersebut berasal dari populasi berdistribusi normal melawan hipotesis tandingan bahwa populasi berdistribusi tidak normal. (Singgih Santoso,2002:323),

\section{Uji Statistik \\ Analisis Korelasi}

Untuk Analisis Korelasi peneliti menggunakan Korelasi Pearson Product Moment untuk mencari kekuatan hubungan variabel bebas (X) dan Variabel tak bebas (Y), dan data berbentuk interval dan rasio (Ir Syofian Siregar, MM, 2013:338)

\section{Analisis Regresi}

Setelah diketahui data kedua variable tersebut dan merupakan data kuantitatif, maka skala pengukuran menggunakan skala rasio. Analisa regresi adalah suatu analisis yang digunakan untuk mendapatkan hubungan antara dua variable atau lebih, sehingga dapat memprediksi kondisi suatu variable apabila variable lain diketahui. Dalam penelitian ini analisis regresi digunakan untuk mengetahui apakah terdapat pengaruh dari kualitas produk terhadap loyalitas pelanggan.

Persamaan regresi yang digunakan adalah regresi linear sederhana karena 
hanya melihat dua variable saja yaitu Kualitas produk sebagai variable independent (X) dan Loyalitas Pelanggan sebagai variable dependent (Y), maka menurut sugiyono (2004) bentuk persamaannya menggunakan rumus sebagai berikut:

$$
\mathrm{Y}=\mathrm{a}+\mathrm{bX}
$$

Keterangan :

$\mathrm{Y}=$ data / subjek pada variable dependent (Loyalitas Pelanggan)

$\mathrm{X}=$ data/ subjek pada variable independent yang memiliki nilai tertentu (Kualitas Produk)

$\mathrm{a}=$ harga $\mathrm{Y}$ bila $\mathrm{X}=0$ (harga constant)

$\mathrm{b}=$ angka arah atau koefisien regresi, yang menunjukan penyebab peningkatan atau penurunan varibel dependent, berdasarkan varibel independent. Apabila b (+) maka terjadi kenaikan dan bila b (-) maka terjadi penurunan.

\section{Koefisien Determinasi}

Koefisien Determinasi bertujuan untuk menghitung besarnya pengaruh variable (X) yang dalam penelititan ini adalah kualitas produk terhadap variable (Y) yang dalam penelitian ini adalah loyalitas produk, dan nilai koefisien determinasi dihitung menggunakan rumus:

$$
\mathrm{KD}=\mathrm{r}^{2} \times 100 \%
$$

Keterangan:

$\mathrm{KD}=$ koefisien determinasi

$\mathrm{r}=$ nilai koefisien korelasi

\section{Pengujian Hipotesis (T Parsial)}

Pengujian ini adalah uji signifikansi dengan uji $\mathrm{T}$ untuk mengetahui apakah ada pengaruh antara variabel $\mathrm{X}$ dan Variabel $\mathrm{Y}$ yang membuktikan $\mathrm{Ho}$ atau $\mathrm{Hi}$ yang akan diterima. Jika Hi diterima maka Ho ditolak, dan begitu juga sebaliknya. Untuk menguji hipotesis yang telah diajukan yaitu kualitas produk terhadap loyalitas pelanggan, digunakan pengujian hipotesis sebagai berikut:
1. Membuat hipotesis dalam uraian kalimat

Ho $: p=0$, tidak terdapat pengaruh signifikan kualitas produk terhadap Loyalitas Pelanggan.

$\mathrm{H} 1: p \neq 0$, terdapat pengaruh signifikan kualitas produk terhadap Loyalitas Pelanggan.

2. Membuat hipotesis dalam bentuk model statistik

Ho : $P=0$

Ho : $P \neq 0$

3. Menentukan taraf signifikan (a)

4. Kaidah pengujian

Uji $t$ hitung, menurut Sugiyono untuk hasil $t$ hitung dapat disimpulkan jika a nilai $t$ hitung $\geq$ nilai $\mathrm{t}$ table maka Ho ditolak, berarti $\mathrm{Hi}$ diterima, atau kualitas produk berpengaruh terhadap loyalitas produk.

$\mathrm{b}$ nilat $t$ hitung $\leq$ nilai t table maka Ho diterima, berarti $\mathrm{Hi}$ ditolak, atau kualitas produk tidak berpengaruh terhadap loyalitas pelanggan

5. Menghitung t hitung dan $\mathrm{t}$ tabel

- Menghitung t hitung

Rumus : $\quad \frac{r \sqrt{n-2}}{\sqrt{1-(r)^{2}}}$

- Menentukan nilai t tabel

Nilai $t$ tabel dapat dicari dengan menggunakan dua sisi, maka nilai a di bagi 2

Rumus : $\mathrm{t}$ tabel $=\mathrm{t}(\mathrm{a} / 2)(\mathrm{n}-2)$

6. Membandingkan $\mathrm{t}$ tabel dan $\mathrm{t}$ hitung tujuan membandingkan untuk mengetahui apakah Ho ditolak atau diterima berdasarkan kaidah pengujian.

7. Mengambil keputusan menerima dan menolak Ho. (Prof. Dr. H.M Burhan Bungin, S.Sos, M.Si, 286: 287).

\section{ANALISIS DATA DAN PEMBAHASAN \\ Identitas Responden}

- sampel dengan jumlah 31 orang, 20 orang berjenis kelamin laki-laki dan 11 orang bejenis kelamin perempuan. 
- pelanggan kartu perdana Indosat Prabayar dari usia 15-20 tahun berjumlah 21 orang, 20-25 tahun berjumlah 6 orang, 25-30 tahun berjumlah 4 orang.

- responden berpendidikan SMP sebanyak 8 orang, berpendidikan SMA 20 orang, berpendidikan D3 sebanyak 2 orang dan untuk pendidikan S1 sebanyak 1 orang.

- pelanggan yang menggunakan kartu selama 6 bulan sebanyak 20 orang, lama pemkaian selama 1 tahun 10 orang dan selama 2 tahun berjumlah 1 orang.

- 4 responden telah menikah dan 27 responden belum menikah.

\section{Uji Validitas}

Uji validitas digunakan untuk mengukur derajat ketepatan dalam setiap item pertanyaan suatu kuesioner, pertanyaan-pertanyaan dalam kuesioner dapat dikatakan valid apabila pertanyaan tersebut mampu mengungkapkan sesuatu yang akan diukur oleh kuesioner tersebut dan apabila nilai korelasi hitung ( $r$ hitung) lebih besar daripada nilai korelasinya $(\mathrm{r}$ tabel). Nilai $\mathrm{r}$ hitung adalah nilai-nilai yang berada dalam kolom "Correlations" pada lembar output spss. Apabila nilai kolom total $r$ Hitung > $r$ tabel, maka item pertanyaan tersebut dapat dikatakan valid. Berdasarkan hasil uji validitas butir instrument Kualitas produk dan hasil uji validitas butir instrument Loyalitas Pelanggan di atas menunjukan bahwa setiap pernyataan memiliki nilai Korelasi ( $r$ hitung) lebih besar dari ( $r$ Kritis) yaitu 0,3 selain itu jika setiap pernyataan nilai nya positif dan besarnya 0,3 ke atas maka validitas instrumen dinyatakan valid.

\section{Uji Reliabilitas}

Uji Reliabilitas digunakan untuk mengukur ketetapan bisa digunakan beberapa kali untuk mengukur objek yang sama yang akan menghasilkan data yang sama pula, disini peneliti menggunakan Metode Alpha Cronbach's jika nilai Alpha Cronbach's lebih besar dari 0,6 maka pernyataan yang dibuat oleh peneliti bisa disebut reliable. Berikut ini adalah tabel hasil uji reliabilitas. Nilai Cronbach's Alpha yang di hasilkan dari kedua variabel tersebut melebihi 0,6 artinya pernyataan yang dibuat oleh peneliti adalah reliable atau dapat di percaya.Pernyataan tersebut dapat diajukan kembali dan memperoleh jawaban yang relatif sama.

\section{Uji Normalitas}

Uji normalitas digunakan untuk menguji apakah model regresi mempunyai distribusi normal atau tidak. Asumsi normalitas sangat penting pada pengujian signifikansi koefisien regresi, pengambilan keputusan bisa dilakukan berdasarkan probabilitas jika probabilitas $>0,5$ maka distribusi dari populasi dianggap normal (Singgih Santoso: 2002, 393). Berikut hasil dari uji normalitas.

Tabel 3. Hasil Uji Normalitas

\begin{tabular}{|l|r|r|r|r|r|r|}
\hline & \multicolumn{3}{|c|}{ Kolmogorov-Smirnov $^{\mathrm{a}}$} & \multicolumn{3}{|c|}{ Shapiro-Wilk } \\
\cline { 2 - 7 } & Statistic & \multicolumn{1}{c|}{ df } & \multicolumn{1}{c|}{ Sig. } & Statistic & \multicolumn{1}{c|}{ df } & \multicolumn{1}{c|}{ Sig. } \\
\hline VAR0000 &, 146 & 31 &, 089 &, 944 & 31 &, 108 \\
1 & & & & & & \\
VAR0000 &, 140 & 31 &, 129 &, 950 & 31 &, 157 \\
2 & & &
\end{tabular}


Data hasil penghitungan spss 22

Dapat dilihat pada tabel di atas hasil dari uji Normalitas Variabel 1 atau Variabel X adalah sebesar 0,089 lebih besar dari 0,05 artinya Variabel $\mathrm{X}$ di nyatakan bersifat normal sedangkan untuk Variabel 2 atau Variabel Y hasil uji normalitasnya sebesar 0,129 lebih besar dari 0,05 artinya Variabel Y bersifat normal.

\section{Gambar 4. Hasil Uji Normalitas Variabel X (Kualitas Produk)}

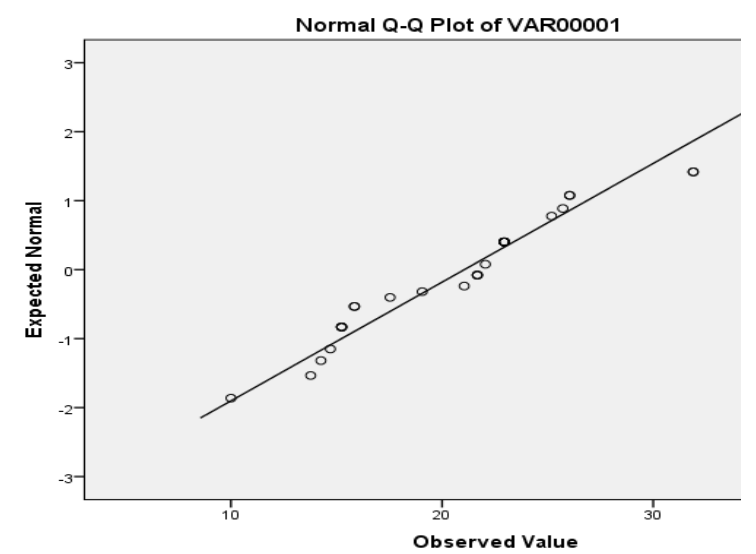

Dapat dilihat pada grafik diatas bahwa

Tabel 4. Hasil Uji Korelasi Correlations

\begin{tabular}{|ll|r|r|}
\hline & & $\begin{array}{r}\text { VAR } \\
0000 \\
1\end{array}$ & $\begin{array}{c}\text { VAR } \\
0000 \\
2\end{array}$ \\
\hline VAR0000 & Pearson & 1 &, $739 *$ \\
1 & Correlation & &, 000 \\
& Sig. (2-tailed) & 31 & 31 \\
\hline & $\mathrm{N}$ &, $739^{*}$ & 1 \\
\hline VAR0000 & Pearson & & \\
2 & Correlation &, 000 & \\
& Sig. (2-tailed) & 31 & 31 \\
\hline
\end{tabular}

**. Correlation is significant at the 0.01

level (2-tailed).

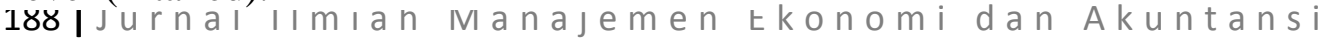

variabel $X$ (kualitas Produk ) titik-titik merapat pada garis ini berarti bahwa Variabel X (Kualitas Produk) bersifat normal.

\section{Gambar 5. Hasil Uji Normalitas Variabel Y (Loyalitas Pelanggan)}

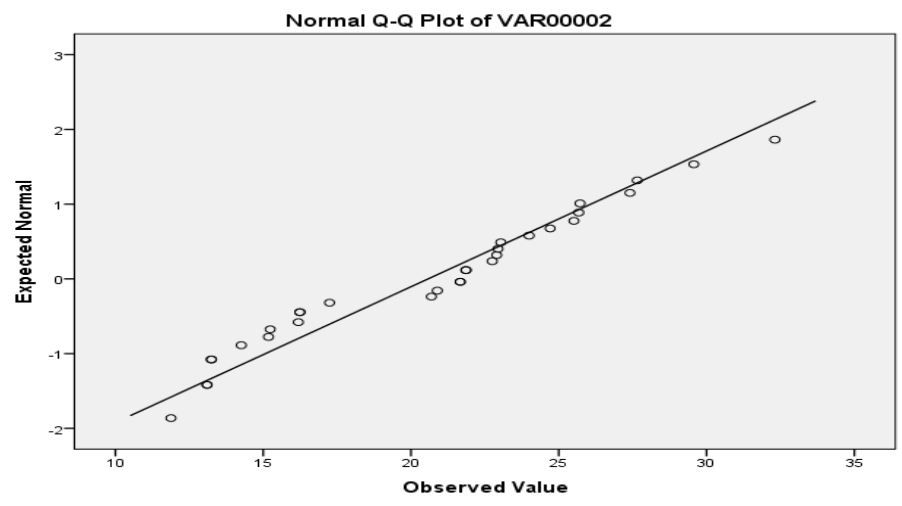

Pada Grafik diatas juga terlihat bahwa Grafik Loyalitas Pelanggantitik-titik nya mendekat pada garis artinya Variabel bersifat normal

\section{Uji Statistik (Korelasi)}

Untuk uji statistik peneliti menggunakan uji Korelasi Pearson Product Moment untuk mencari kekuatan hubungan antara variabel $\mathrm{X}$ dan Variabel Y. Berikut ini tabel hasil penghitungan korelasi product moment menggunakan spss 22

Dapat dilihat dari tabel di atas bahwa nilai variabel 1 (Independent) dan variabel 2 (dependent) korelasi nya sebesar 0,739 artinya kekuatan hubungan antara variabel $\mathrm{X}$ dan Variabel Y dinyatakan termasuk daam 
kategori kuat karena hasil korelasi positif (+). Sebesar 73,9\% sehingga jika kualitas produk indosat IM3 semakin tinggi maka Loyalitas pelanggan akan semakin tinggi pula.

\section{Analisis Regresi Linier Sederhana}

Analisis Regresi adalah analisis yang digunakan untuk mendapatkan hubungan antara dua variabel atau lebih, persamaan regresi yang akan digunakan adalah regresi linear sederhana. Bentuk umum regresi linear sederhana adalah sebagai berikut:

$$
\mathbf{Y}=\mathbf{a}+\mathbf{b X}
$$

Dimana $: \mathrm{Y}=$ Variabel dependent ( Loyalitas Pelanggan )

$$
\begin{aligned}
& a=\text { Nilai konstanta } \\
& b=\text { Koefisien regresi } \\
& X=\text { Variabel independent }
\end{aligned}
$$

(Kualitas Produk)

Berdasarkan hasil perhitungan program IBM Stastitical for Product and Service Solution (SPSS) versi 22. Didapat hasil dari regresi linear sederhana sebagai

\begin{tabular}{|c|c|c|c|c|c|}
\hline \multirow[b]{2}{*}{ Model } & \multicolumn{2}{|c|}{$\begin{array}{c}\text { Unstandardized } \\
\text { Coefficients }\end{array}$} & \multirow{2}{*}{$\begin{array}{c}\text { Standardi } \\
\text { zed } \\
\text { Coefficie } \\
\text { nts } \\
\\
\text { Beta }\end{array}$} & \multirow[b]{2}{*}{$\mathrm{t}$} & \multirow[b]{2}{*}{ Sig. } \\
\hline & B & $\begin{array}{l}\text { Std. } \\
\text { Error }\end{array}$ & & & \\
\hline $\begin{array}{ll}1 & \text { (Consta } \\
& \mathrm{nt})\end{array}$ & 4,587 & 2,162 & & 2,122 &, 043 \\
\hline$X$ & ,655 &, 085 & ,819 & 7,676 & ,000 \\
\hline
\end{tabular}
berikut :

Tabel 5. Hasil Uji Regresi Linier Sederhana Coefficients $^{\mathrm{a}}$

Berdasarkan tabel di atas nilai Constant(a) adalah 4,587 sedangkan nilai $X$ (b) adalah 0,655 sehingga persamaan regresinya dapat ditulis

$$
\mathrm{Y}=\mathbf{4 , 5 8 7 + 0 , 6 5 5} \mathrm{X}
$$

Dimana $: Y=$ Variabel dependent ( Loyalitas Pelanggan )

$$
\begin{aligned}
& a=\text { Nilai konstanta } \\
& b=\text { Koefisien regresi }
\end{aligned}
$$$$
\mathrm{X}=\text { Variabel }
$$

independent (Kualitas Produk)

Hasil Konstanta sebesar 4,587 menyatakan bahwa jika tidak ada nilai trust (X) maka nilai partisipasi sebesar 4,587. Koefisien regresi $\mathrm{X}$ sebesar 0,655 menyatakan bahwa setiap penambahan 1 nilai trust(x) maka nilai pasrtisipasi bertambah 0,655 artinya jika kualitas produk mengalami peningkatan sebesar 1 nilai maka loyalitas pelanggan akan mengalami kenaikan sebesar 65,5\%,

\section{Koefisien Determinasi}

Untuk mengetahui persentasi pengaruh variabel independen (kualitas produk) terhadap variabel dependen (Loyalitas Pelanggan), dihitung dengan uji koefisien determinasi. Berikut tabel hasil penghitungan program IBM Stastitical for Product and Service Solution (SPSS) versi 22. 
Tabel 6. Hasil Koefisien Determinasi

\begin{tabular}{|l|c|r|r|r|}
\hline Model & R & R Square & $\begin{array}{c}\text { Adjusted R } \\
\text { Square }\end{array}$ & $\begin{array}{c}\text { Std. Error of } \\
\text { the Estimate }\end{array}$ \\
\hline 1 &, $819^{\mathrm{a}}$ &, 670 &, 659 & 3,21515 \\
\hline
\end{tabular}

a. Predictors: (Constant), VAR00001

Tabel diatas menjelaskan bahwa besarnya nilai korelasi sebesar 0,819 dan dijelaskan besarnya presentasi pengaruh Variabel Independen terhadap Variabel Dependen. Dari output tersebut diperoleh Koefisien Determinasi (R2) sebesar 67\% sedangkan sisanya 33\% dipengaruhi oleh variabel lain.

\section{Uji Hipotesis}

Pengujian ini membuktikan Ho atau $\mathrm{Hi}$ yang akan diterima. Jika $\mathrm{Hi}$ diterima maka Ho di tolak dan sebaliknya, untuk melihat ada atau tidak nya pengaruh antara varibel $\mathrm{X}$ (kualitas produk) dan Variabel Y (loyalitas pelanggan). Dapat dilihat pada tabel 4.20, jika nilai propabillity $\mathrm{t}<0,05$ maka Ha diterima, sedangkan jika nilai probability $\mathrm{t}>0,05$ maka Ha ditolak.

\section{Tabel 7. Hasil Uji Regresi Parsial T}

\begin{tabular}{|c|c|c|c|c|c|}
\hline \multirow[b]{2}{*}{ Model } & \multicolumn{2}{|c|}{$\begin{array}{l}\text { Unstandardized } \\
\text { Coefficients }\end{array}$} & \multirow{2}{*}{$\begin{array}{c}\begin{array}{c}\text { Standardized } \\
\text { Coefficients }\end{array} \\
\text { Beta }\end{array}$} & \multirow[b]{2}{*}{$\mathrm{t}$} & \multirow[b]{2}{*}{ Sig. } \\
\hline & $\mathrm{B}$ & Std. Error & & & \\
\hline (Constant) & 4,587 & 2,162 & & 2,122 &, 043 \\
\hline$X$ & ,655 &, 085 & ,819 & 7,676 &, 000 \\
\hline
\end{tabular}

Sumber data hasil spss 22

Berkut hasil Uji Signifikansi berdasarkan tabel 4.26:

1. Membuat hipotesis dalam urain kalimat

Ho = Tidak terdapat pengaruh signifikan kualitas produk terhadap loyalitas pelanggan

$\mathrm{Hi}=$ Terdapat pengaruh signifikan kualitas produk terhadap loyalitas pelanggan

2. Membuat hipotesis dalam bentuk model statistik

Ho: $\mathrm{P}=0$

Ha: $\mathrm{P} \neq 0$

\section{Menentukan taraf signifikansi}

Taraf signifikansi di tentukan $0,000<0,05$ atau sebesar 0,05

4. Kaidah Pengujian

Jika $\mathrm{t}$ tabel $\leq \mathrm{t}$ hitung, $\leq \mathrm{t}$ tabel, maka Ho diterima, jika t hitung $>\mathrm{t}$ tabel, maka Ho di tolak.

5. Menghitung t hitung dan t tabel $\mathrm{T}$ hitung dapat di lihat pada tabel 4.26 yaitu sebesar 7,676 sedangkan $t$ tabel sebesar 1,696 dapat dilihat pada lampiran t tabel.

6. Membandingkan $\mathrm{t}$ tabel dan $\mathrm{t}$ hitung t hitung : 7,676 
t tabel : 1,696

t hitung $>\mathrm{t}$ tabel

7. Mengambil keputusan menerima dan menolak Ho

t hitung > t tabel, maka Ho ditolak, dapat dilihat bahwa 7,676>1,696 artinya Ho ditolak atau Ha diterima, kesimpulan yang dapat diambil yaitu terdapat pengaruh yang signifikan kuailtas produk terhadap loyalitas pelanggan.

2. Perusahaan perlu meningkatkan item loyalitas seperti Melakukan pembelian berulang yang teratur, membeli antara lini produk dan jasa, mereferensikan kepada orang lain, menunjukan kekebalan terhadap tarikan dari pesaing. Dikarenakan pelanggan memberikan respon yang cukup baik akan tetapi itemitem tersebut memiliki skor yang sangat rendah artinya pelanggan lebih mungkin untuk berpindah kepada produk pesaing dibandingkan loyal terhadap produk IM3. Untuk meningkatkan item loyalitas tersebut perusahaan dapat melakukan pendekatan terhadap konsumen dengan cara mengadakan event-event tertentu bagi pelanggan, memberikan penghargaan terhadap konsumen yang loyal, mengawasi pelanggan yang mulai kecewa, memberikan pelayanan dengan menyajikan keunggulan di mata konsumen

\section{SIMPULAN DAN SARAN}

Kualitas produk Indosat sudah cenderung baik hal ini dapat dilihat dari ke lima indikator variabel . Terdapat beberapa pernyataan yang memiliki skor tertinggi yaitu Assurance (Kredibilitas, Keamanan, Kompetensi), Empathy ( Akses mudah, Komunikasi yang baik, Pemahaman Pelanggan, dan Responsiveness ( Kinerja yang dapat diandalkan).

2. Sedangkan untuk loyalitas pelanggan di nilai cukup baik, pernyataan yang memiliki skor tertinggi yaitu melakukan pembelian yang berulang dan mereferensikan kepada orang lain sedangkan pernyataan yang memilki skor terendah adalah membeli antar lini produk dan jasa, menunjukan kekebalan terhadap tarikan pesaing.

3. Hasil analisis diperoleh bahwa variabel kualitas produk (x) memiliki koefisien regresi sebesar $67 \%$ (bertanda positif) terhadap variabel Loyalitas pelanggan $(\mathrm{Y})$ dan nilai thitung sebesar 7,676 dengan tingkat signifikansi $0,000 \quad(<0,050)$. Hal ini berarti, $76,76 \%$ variabilitas loyalitas pelanggan dipengaruhi oleh kualitas produk sisanya sebesar $33 \%$ variabel loyalitas pelanggan dipengaruhi oleh variabel lain di luar variabel yang diteliti yaitu harga, Tempat, Promosi, Manusia, Proses, Perlengkapan Bangunan/ Lingkungan Fisik.

1. Perusahaan perlu mempertahankan kualitas produk IM3 pada item assurance ,empathy dan responsiveness karena ketiga item ini dinilai baik oleh para pelanggannya sedangkan pada item tangibles dan responsiveness perlu ditingkatkan dikarenakan pada item ini pelanggan memberikan respon tidak baik. Untuk meningkatkan item tangibles perusahaan dapat melakukannya dengan cara menyediakan customer service bebas pulsa sehingga pelanggan yang ingin mengetahui cara penggunaan kartu tidak hanya membaca lewat kemasan produk akan tetapi dapat menghubungi langsung operator tanpa beban harus mengeluarkan pulsa sedangkan untuk meningkatkan item responsiveness dapat dilakukan dengan cara membuat kemasan yang menarik dari yang sebelumnya dengan warna-warna yang mencolok khas anak muda. Hal ini dilakukan karena jika kualitas produk IM3 Indosat baik maka hal ini akan menimbulkan kepuasan pelanggan sehingga mendorong pelanggan untuk melakukan pembelian ulang, jika pelanggan merasa puas dengan jasa yang digunakan maka akan mempengaruhi 
pelanggan untuk loyal kepada produk Indosat IM3.

3. Kualitas pelayanan dapat membentuk suatu image suatu perusahaan. Apabila perusahaan mempunyai image yang baik bagi pelanggannya maka hal ini akan membuat pelanggan menjadi loyal dan tidak berpindah pada merk lain dikarenakan mereka mempercayai produk Indosat IM3 mempunyai kualitas yang baik meskipun produk lain memberikan promo yang lebih menarik. Tapi sebalik nya jika pelanggan sudah tidak percaya pada perusahaan dikarenakan citra yang buruk dapat dipastikan pelanggan akan enggan untuk melakukan pembelian yang berulang sehingga dapat menimbulkan ketidak loyalan pada pelanggan, pelanggan akan berpindah pada produk lain dengan citra yang lebih baik

\section{DAFTAR PUSTAKA}

Hurriyati Ratih,DR,M.SI,(2010). Bauran Pemasaran dan Loyalitas Konsumen. Bandung : Alfabeta,.

Sugiyono Prof, DR,(2014). Metode Penelitian Administrasi. Bandung : Alfabeta.

Kotler, Philip \& L. Keller Kevin,(2012). Manajemen Pemasaran jilid 1. Jakarta : Indeks.

Lovelock Christopher,(2011). Wirtz Jochen, Musrry Jacky, Pemasaran Jasa jilid 1 edisi ketujuh. Jakarta : Erlangga.

Kotler \& Amstrong, (2010). PrinsipPrinsip Pemasaran, Jakarta : Erlangga.

Sugiyono, (2009). Metode Penelitian Kuantitatif, Kualitatif, Bandung : CV Alfabeta, Anggota IKAPI.

Griffin Jill, (2007). Manajemen Pelayanan Jasa, Jakarta : Erlangga

Sugiyono, Prof.Dr. ( 2014). Metode Penelitian Kuantitatif Kualitatif Dan R\&D, Bandung : Alfabeta.

Lupiyoadi Rambat. (2013). Manajemen
Pemasaran Jasa, Jakarta : Salemba Empat.

Abdullah Thamrin, Prof, Dr, M.M, MP.D, Tantri Francis,DR, SE, MM. (2012). Manajemen Pemasaran, Jakarta : Raja Grafindo Persada.

Tjiptono Fandy, Ph. D, Chandra Gregorius.(2012). Pemasaran Strategik, Yogyakarta : CV. Andi.

Prof. Dr. H.M Burhan Bungin, S.Sos, M.Si,(2005) Metodologi Penelitian Kuantitatif edisi kedua, Jakarta: Kencana Prenada Media Group

Alma,Buchari.(2009).Manajemen

Pemasaran dan Pemasaran

Jasa.Edisi Revisi.Bandung :CV.Alfabeta.

Santoso Singgih. (2002), Statistika Parametrik dengan penghitungan manual dan SPSS. Bandung: Alfabeta.

www. Indosat Ooredoo.com, 6 Desember 2015, pukul :10.09: Bandung

(http://www.anneahira.com), 22 Februari 2016, pukul : 20.30: Bandung (http://okezone.com), 22 Februari 2016, Pukul : 21.30 : Bandung 